Article

\title{
Synthesis and Evaluation of Phenylxanthine Derivatives as Potential Dual A2AR Antagonists/MAO-B Inhibitors for Parkinson's Disease
}

\author{
Xuebao Wang, Chao Han, Yong Xu, Kaiqi Wu, Shuangya Chen, Mangsha Hu, Luyao Wang, Yun Ye \\ and Faqing Ye *
}

School of Pharmaceutical Sciences, Wenzhou Medical University, Wenzhou 325035, China; wangxuebao@wmu.edu.cn (X.W.); lab1509@163.com (C.H.); x13766995321@163.com (Y.X.); k13578902233@163.com (K.W.); dsd1801@163.com (S.C.); m199720@sina.com (M.H.); w1386565198@163.com (L.W.); 13957720727@163.com (Y.Y.)

* Correspondence: yfq4340@163.com; Tel.: +86-577-8669-9156

Received: 15 May 2017; Accepted: 14 June 2017; Published: 17 June 2017

\begin{abstract}
The aim of this research was to prove the speculation that phenylxanthine (PX) derivatives possess adenosine $\mathrm{A} 2 \mathrm{~A}$ receptor (A2AR)-blocking properties and to screening and evaluate these PX derivatives as dual A2AR antagonists/MAO-B inhibitors for Parkinson's disease. To explore this hypothesis, two series of PX derivatives were prepared and their antagonism against A2AR and inhibition against MAO-B were determined in vitro. In order to evaluate further the antiparkinsonian properties, pharmacokinetic and haloperidol-induced catalepsy experiments were carried out in vivo. The PX-D and PX-E analogues acted as potent A2AR antagonists with Ki values ranging from 0.27 to $10 \mu \mathrm{M}$, and these analogues displayed relatively mild MAO-B inhibition potencies, with inhibitor dissociation constants (Ki values) ranging from 0.25 to $10 \mu \mathrm{M}$. Further, the compounds PX-D-P6 and PX-E-P8 displayed efficacious antiparkinsonian properties in haloperidol-induced catalepsy experiments, verifying that these two compounds were potent A2AR antagonists and MAO-B inhibitors. We conclude that PX-D and PX-E analogues are a promising candidate class of dual-acting compounds for treating Parkinson's disease.
\end{abstract}

Keywords: adenosine A2AR antagonist; monoamine oxidase B inhibitor; phenylxanthine derivatives; parkinson's disease

\section{Introduction}

Parkinson's disease (PD) is the second most common progressive neurodegenerative disorder after Alzheimer's disease and it affects approximately $1 \%$ of the population over the age of $65[1,2]$. $\mathrm{PD}$ is primarily caused by dysfunction of dopaminergic neurons, and the therapy of PD is largely centered on dopamine replacement strategies with the dopamine agonist and dopamine precursor levodopa drugs [3]. Ongoing studies have shown new insights regarding the pathophysiology of PD, which suggest that the non-dopaminergic system is also affected and may correlate with multiple PD symptoms [4,5]. Non-dopaminergic targets are potentially used to reduce levodopa dosage or to treat non-levodopa-responsive symptoms.

A2AR is not widely distributed in the central nervous system, but rather it is located in selective areas of the brain. It is expressed richly in the nigrostriatum, where it co-localizes with dopamine $\mathrm{D} 2$ receptors on output neurons [6]. Besides, A2AR is also located in glutamatergic terminals and controls the release of glutamate from afferent glutamatergic terminals which trigger the activity in the striatum, and A2AR is highly important in the control of voluntary movement [7-9], so a lot of research groups have dedicated significant efforts towards the discovery of selective A2AR antagonists for the 
therapy of PD [10]. Istradefylline was the first A2AR antagonist which was evaluated as an adjunctive therapy with levodopa with motor fluctuations in PD patients. In 2013, Istradefylline was licensed in Japan, because of its positive results and a further multicenter Phase III trial is ongoing in the U.S. [11]. Moreover, several Phase III studies (with drugs such as preladenant, tozadenant and caffeine) have already been conducted with positive results [10]. In a word, A2AR antagonists represent hopeful adjunctives to dopamine replacement treatment for PD.

In our previous studies [12,13], we have reported that a group of PX derivatives are potent inhibitors of monoamine oxidase $\mathrm{B}$ (MAO-B) which are known to possess antiparkinsonian properties [14,15]. Since xanthine derivatives such as caffeine, CSC and istradefylline (Figure 1) have the ability to block A2AR, we speculated that PX derivatives (Figure 2) might also have similar ability. A similar idea had been verified with the compound 8-(3-chlorostyryl) caffeine [16]. The aim of this research was to explore the speculation that PX derivatives possess antiparkinsonian properties and to screen and evaluate these PX derivatives as dual A2AR antagonists/MAO-B inhibitors for treatment of Parkinson's disease. The dual molecular mechanism of the possible A2AR antagonists/MAO-B inhibitors is shown in Figure 3 [8,17].<smiles>Cn1c(=O)c2c(ncn2C)n(C)c1=O</smiles>

1, Caffeine<smiles>Cn1c(=O)c2c(nc(/C=C/c3cccc(Cl)c3)n2C)n(C)c1=O</smiles>

$2, \operatorname{CSC}$<smiles>CCn1c(=O)c2c(nc(/C=C/c3ccc(OC)c(OC)c3)n2C)n(CC)c1=O</smiles>

3, Istradefylline

Figure 1. The structures of adenosine A2AR antagonists caffeine (1), CSC (2), and istradefylline (3).

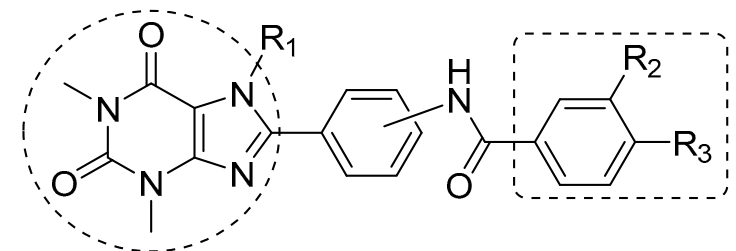

PX-D

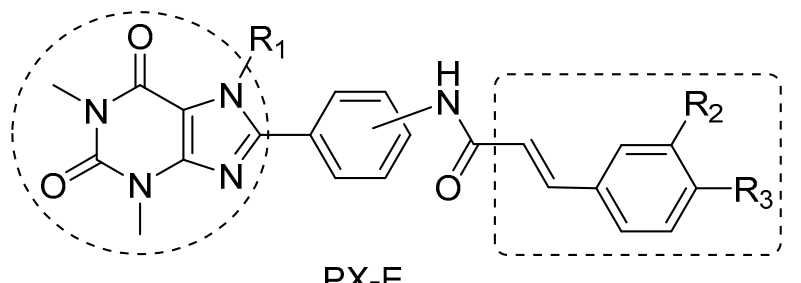

PX-E

Figure 2. Parent nucleus for the target compounds of the PX-D and PX-E series. 

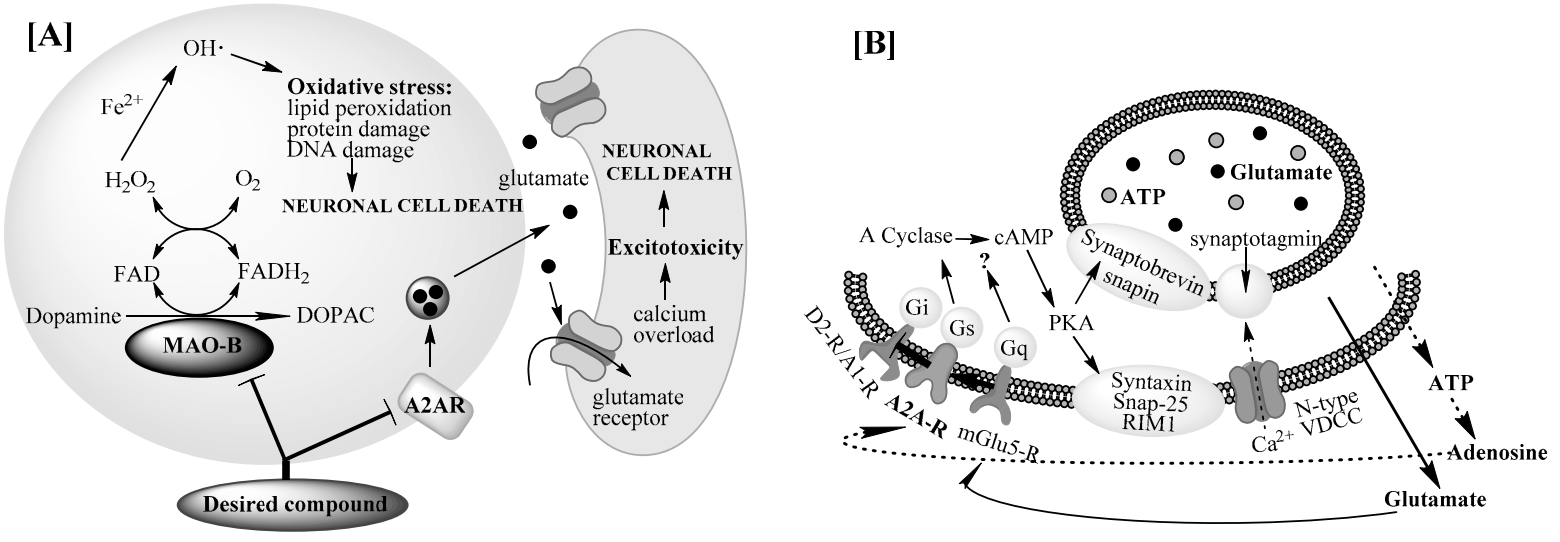

Figure 3. (A) Dual molecular mechanism of the A2AR antagonists/MAO-B inhibitors. Desirable compounds will prevent neuron death by antioxidant effects via MAO-B inhibition and prevention of excitotoxic release of glutamate via A2AR antagonism. (B) Schematic instruction of glutamate release by the ability of A2A receptors: strong cortico-limbic-thalamic input facilitate A2A and mGlu5 synergistic activation results in increases in the probability of glutamate release.

\section{Results and Discussion}

\subsection{Chemistry}

Scheme 1 shows the general route for the synthesis of phenylxanthine derivatives of series PX-D and PX-E. The compounds were synthesized with yields between 40.7-56.3\% following a six-step procedure.
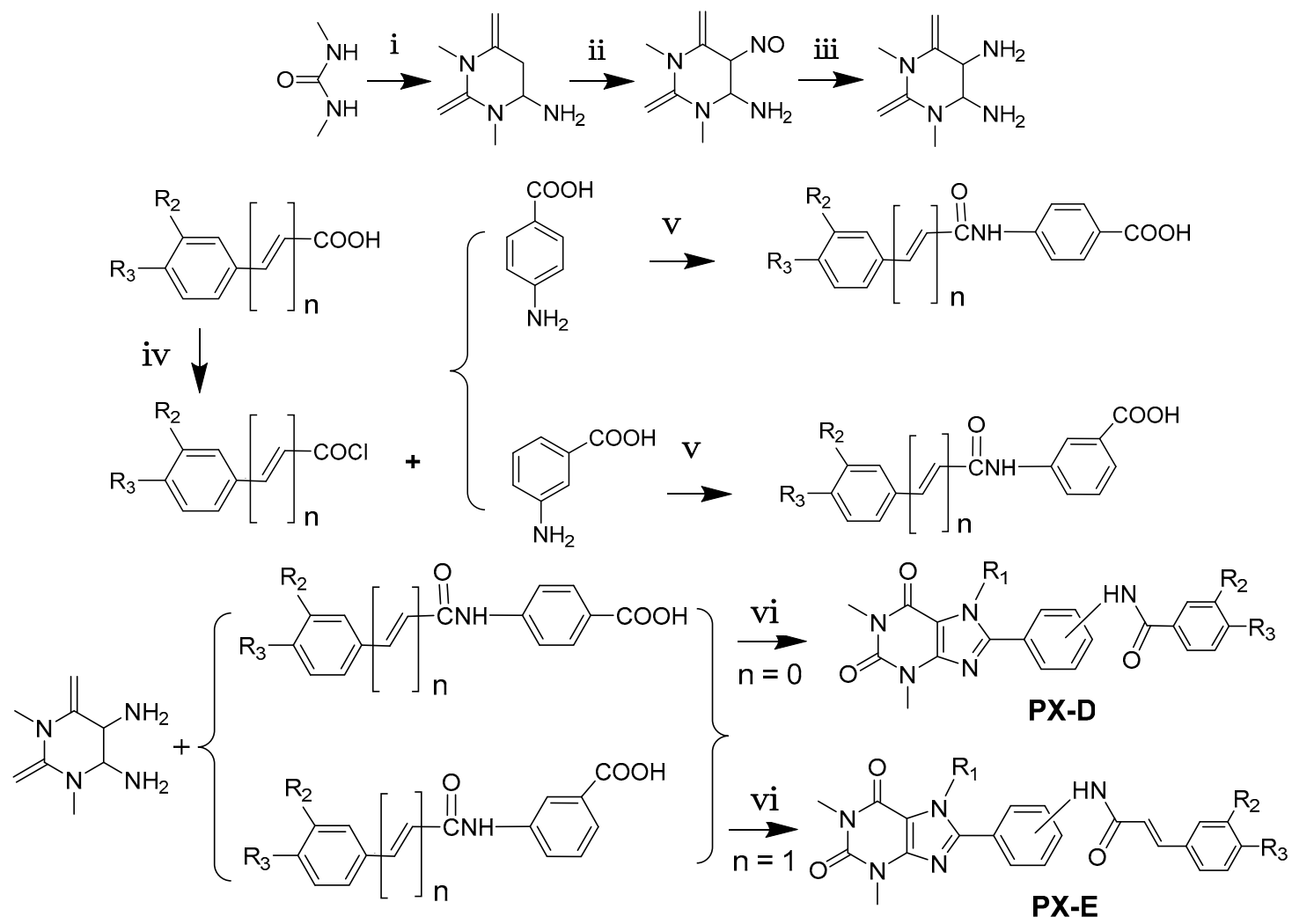

Scheme 1. General method for the synthesis of phenylxanthine derivatives of series PX-D and PX-E, $n=0$ or 1 . 


\subsection{Structure-Activity Relationship between Test Compounds and $A 2 A R$}

Initially, a series of PX derivatives were analysed with the objective of screening novel, potent and selective A2AR antagonists. The data obtained are listed in Table 1.

Table 1. Biological data and structure-activity relationship (SAR) of A2AR affinities (Ki) and MAO-B inhibitory potencies (Ki) for test compounds.

\begin{tabular}{|c|c|c|c|c|c|c|}
\hline Compound & -HNCO & $\mathbf{R}_{1}$ & $\mathbf{R}_{2}$ & $\mathbf{R}_{3}$ & Ki hA2AR $(\mu M)^{1}$ & Ki hMAO-B $(\mu M)^{1}$ \\
\hline Istradefylline & & & & & $0.05 \pm 0.01$ & $>10$ \\
\hline PX-D-P1 & para- & $\mathrm{H}$ & $\mathrm{H}$ & $\mathrm{H}$ & $2.31 \pm 0.31$ & $1.32 \pm 0.11$ \\
\hline PX-D-P2 & para- & $\mathrm{H}$ & $\mathrm{H}$ & $\mathrm{CH}_{3}$ & $2.87 \pm 0.21$ & $2.06 \pm 0.25$ \\
\hline PX-D-P3 & para- & $\mathrm{H}$ & $\mathrm{H}$ & $\mathrm{OCH}_{3}$ & $2.67 \pm 0.14$ & $2.94 \pm 0.31$ \\
\hline PX-D-P4 & para- & $\mathrm{H}$ & $\mathrm{Cl}$ & $\mathrm{H}$ & $1.52 \pm 0.16$ & $0.25 \pm 0.05$ \\
\hline PX-D-P5 & para- & $\mathrm{H}$ & $\mathrm{OCH}_{3}$ & $\mathrm{OCH}_{3}$ & $4.27 \pm 0.51$ & $1.92 \pm 0.25$ \\
\hline PX-D-P6 & para- & $\mathrm{CH}_{3}$ & $\mathrm{H}$ & $\mathrm{H}$ & $0.33 \pm 0.09$ & $0.29 \pm 0.03$ \\
\hline PX-D-P7 & para- & $\mathrm{CH}_{3}$ & $\mathrm{H}$ & $\mathrm{CH}_{3}$ & $0.39 \pm 0.06$ & $1.21 \pm 0.15$ \\
\hline PX-D-P8 & para- & $\mathrm{CH}_{3}$ & $\mathrm{H}$ & $\mathrm{OCH}_{3}$ & $1.19 \pm 0.12$ & $0.47 \pm 0.12$ \\
\hline PX-D-P9 & para- & $\mathrm{CH}_{3}$ & $\mathrm{Cl}$ & $\mathrm{H}$ & $0.27 \pm 0.08$ & $1.51 \pm 0.19$ \\
\hline PX-D-P10 & para- & $\mathrm{CH}_{3}$ & $\mathrm{OCH}_{3}$ & $\mathrm{OCH}_{3}$ & $1.34 \pm 0.16$ & $2.97 \pm 0.37$ \\
\hline PX-D-M1 & meta- & $\mathrm{H}$ & $\mathrm{H}$ & $\mathrm{H}$ & $2.91 \pm 0.21$ & $3.11 \pm 0.42$ \\
\hline PX-D-M2 & meta- & $\mathrm{H}$ & $\mathrm{H}$ & $\mathrm{CH}_{3}$ & $4.51 \pm 0.57$ & $2.17 \pm 0.29$ \\
\hline PX-D-M 3 & meta- & $\mathrm{H}$ & $\mathrm{H}$ & $\mathrm{OCH}_{3}$ & $3.77 \pm 0.55$ & $2.57 \pm 0.37$ \\
\hline PX-D-M 4 & meta- & $\mathrm{H}$ & $\mathrm{Cl}$ & $\mathrm{H}$ & $3.61 \pm 0.41$ & $1.27 \pm 0.18$ \\
\hline PX-D-M5 & meta- & $\mathrm{H}$ & $\mathrm{OCH}_{3}$ & $\mathrm{OCH}_{3}$ & $4.99 \pm 0.75$ & $2.36 \pm 0.31$ \\
\hline PX-D-M6 & meta- & $\mathrm{CH}_{3}$ & $\mathrm{H}$ & $\mathrm{H}$ & $2.03 \pm 0.25$ & $2.26 \pm 0.29$ \\
\hline PX-D-M7 & meta- & $\mathrm{CH}_{3}$ & $\mathrm{H}$ & $\mathrm{CH}_{3}$ & $2.78 \pm 0.33$ & $2.57 \pm 0.31$ \\
\hline PX-D-M8 & meta- & $\mathrm{CH}_{3}$ & $\mathrm{H}$ & $\mathrm{OCH}_{3}$ & $3.05 \pm 0.36$ & $2.86 \pm 0.21$ \\
\hline PX-D-M9 & meta- & $\mathrm{CH}_{3}$ & $\mathrm{Cl}$ & $\mathrm{H}$ & $2.44 \pm 0.21$ & $0.76 \pm 0.11$ \\
\hline PX-D-M10 & meta- & $\mathrm{CH}_{3}$ & $\mathrm{OCH}_{3}$ & $\mathrm{OCH}_{3}$ & $3.59 \pm 0.36$ & $2.54 \pm 0.31$ \\
\hline PX-E-P1 & para- & $\mathrm{H}$ & $\mathrm{H}$ & $\mathrm{H}$ & $4.97 \pm 0.59$ & $8.11 \pm 1.03$ \\
\hline PX-E-P2 & para- & $\mathrm{H}$ & $\mathrm{H}$ & $\mathrm{F}$ & $3.41 \pm 0.47$ & $9.36 \pm 1.21$ \\
\hline PX-E-P3 & para- & $\mathrm{H}$ & $\mathrm{CF}_{3}$ & $\mathrm{H}$ & $5.18 \pm 0.67$ & $4.22 \pm 0.55$ \\
\hline PX-E-P4 & para- & $\mathrm{H}$ & $\mathrm{Cl}$ & $\mathrm{H}$ & $6.43 \pm 0.98$ & $1.75 \pm 0.15$ \\
\hline PX-E-P5 & para- & $\mathrm{CH}_{3}$ & $\mathrm{H}$ & $\mathrm{H}$ & $1.46 \pm 0.17$ & $>10$ \\
\hline PX-E-P6 & para- & $\mathrm{CH}_{3}$ & $\mathrm{H}$ & $\mathrm{F}$ & $0.79 \pm 0.11$ & $5.04 \pm 0.53$ \\
\hline PX-E-P7 & para- & $\mathrm{CH}_{3}$ & $\mathrm{CF}_{3}$ & $\mathrm{H}$ & $1.98 \pm 0.15$ & $>10$ \\
\hline PX-E-P8 & para- & $\mathrm{CH}_{3}$ & $\mathrm{Cl}$ & $\mathrm{H}$ & $0.85 \pm 0.11$ & $0.63 \pm 0.11$ \\
\hline PX-E-M1 & meta- & $\mathrm{H}$ & $\mathrm{H}$ & $\mathrm{H}$ & $9.65 \pm 0.98$ & $3.42 \pm 0.32$ \\
\hline PX-E-M2 & meta- & $\mathrm{H}$ & $\mathrm{H}$ & $\mathrm{F}$ & $7.23 \pm 0.86$ & $2.48 \pm 0.23$ \\
\hline PX-E-M3 & meta- & $\mathrm{H}$ & $\mathrm{CF}_{3}$ & $\mathrm{H}$ & $7.44 \pm 0.91$ & $2.63 \pm 0.31$ \\
\hline PX-E-M4 & meta- & $\mathrm{H}$ & $\mathrm{Cl}$ & $\mathrm{H}$ & $9.58 \pm 1.13$ & $>10$ \\
\hline PX-E-M5 & meta- & $\mathrm{H}$ & $\mathrm{OCH}_{3}$ & $\mathrm{OCH}_{3}$ & $>10$ & $2.11 \pm 0.19$ \\
\hline PX-E-M6 & meta- & $\mathrm{CH}_{3}$ & $\mathrm{H}$ & $\mathrm{H}$ & $5.25 \pm 0.65$ & $3.72 \pm 0.52$ \\
\hline PX-E-M7 & meta- & $\mathrm{CH}_{3}$ & $\mathrm{H}$ & $\mathrm{F}$ & $7.74 \pm 0.92$ & $2.58 \pm 0.37$ \\
\hline PX-E-M8 & meta- & $\mathrm{CH}_{3}$ & $\mathrm{CF}_{3}$ & $\mathrm{H}$ & $7.1 \pm 0.84$ & $4.76 \pm 0.68$ \\
\hline PX-E-M9 & meta- & $\mathrm{CH}_{3}$ & $\mathrm{Cl}$ & $\mathrm{H}$ & $9.18 \pm 1.23$ & $2.93 \pm 0.41$ \\
\hline PX-E-M10 & meta- & $\mathrm{CH}_{3}$ & $\mathrm{OCH}_{3}$ & $\mathrm{OCH}_{3}$ & $6.24 \pm 0.77$ & $2.55 \pm 0.24$ \\
\hline
\end{tabular}

${ }^{1} \mathrm{Ki}$ values were converted from $\mathrm{IC}_{50}$ values, by means of the method of Cheng and Prusoff. The determinations were performed in duplicate and the values are expressed as mean $\pm \mathrm{SD}$.

Most of the PX derivatives showed good binding affinity, with Ki values in the range of 0.27-10 $\mu \mathrm{M}$ for human A2AR. In general, PX-D derivatives showed better binding affinity than PX-E derivatives; para-substituents on the phenylxanthine with -HNCO moieties lead to better activity than meta-substituents. Methyl substituents on the $\mathrm{R}_{1}$ position are more favorable than hydrogen atoms; on the $\mathrm{R}_{2}$ and $\mathrm{R}_{3}$ positions, electron-donating $\mathrm{CH}_{3}$ or $-\mathrm{OCH}_{3}$ groups showed poorer $\mathrm{Ki}$ values than $-\mathrm{H}$ or electron-withdrawing groups like $-\mathrm{Cl}$ or $-\mathrm{F}$, except for the stronger electron-withdrawing group $-\mathrm{CF}_{3}$. In addition, when both of the $\mathrm{R}_{2}$ and $\mathrm{R}_{3}$ positions contained $-\mathrm{OCH}_{3}$, the Ki values are generally 
poor. The larger electron withdrawing effect and steric hindrance between test compounds and A2AR may be the reason for the different affinity. The potencies of the test compounds antagonizing A2AR were assayed by radioligand binding experiments [18]. The concentration-response curve for the test compounds versus [3H]ZM241385 are exemplified with PX-D-P6 (Figure 4). This compound was picked out as one of the potent antagonists, with a Ki value of $0.33 \pm 0.07 \mu \mathrm{M}$.

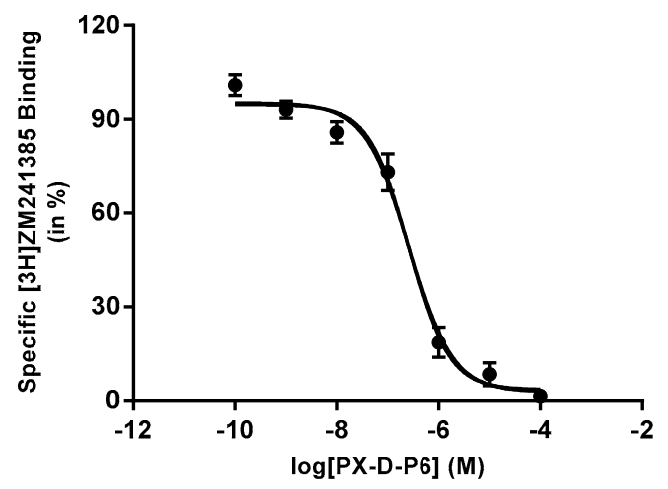

Figure 4. The sigmoidal concentrations-response curve of specific [3H]ZM241385 binding at human A2AR expressed in HEK293. The A2AR proteins were incubated with the radiolabelled compound for $30 \mathrm{~min}$ and exposed to different concentrations $\left(10^{-4}, 10^{-5}, 10^{-6}, 10^{-7}, 10^{-8}, 10^{-9}, 10^{-10} \mathrm{M}\right)$ of the compound PX-D-P6. Results are expressed as the percentage of the control binding. The meaning of $100 \%$ is that A2A receptors of incubating membranes are all bonded with [3H]ZM241385, and binding rate of test compounds close to zero. The experiments were performed in duplicate and the values are displayed as mean $\pm \mathrm{SD}$.

\subsection{Structure-Activity Relationship between Compounds and MAO-B}

As shown in Table 1, most of the PX derivatives were found to exhibit better MAO-B inhibition activity than that of istradefylline, especially PX-D-P4, which showed a better selectivity with an inhibition rate of $0.25 \mu \mathrm{M}$ (Ki value). Concerning the structures, PX-D analogues showed better inhibitory potencies than PX-E analogues.

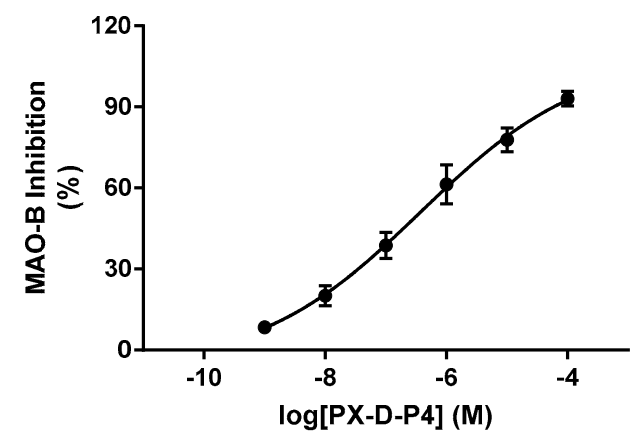

Figure 5. Inhibition curve of compound PX-D-P4 on MAO-B activity. The $\mathrm{IC}_{50}$ value was calculated by fitting the data, using nonlinear least-squares regression analysis. Results are expressed as the percentage of the MAO-B activity inhibition. The meaning of $100 \%$ is that MAO-B activity has been inhibited to the lowest activity for converting luminogenic MAO-B substrate to luciferin, which can produce light, and the produced light intensity is near to the level of the substrate absence. The experiments were performed in duplicate and the values are displayed as mean $\pm \mathrm{SD}$.

para-Substituents on the phenylxanthine with - $\mathrm{HNCO}$ show better inhibition activity than meta-substituents. When both of the $\mathrm{R}_{2}$ and $\mathrm{R}_{3}$ position were occupied by $-\mathrm{OCH}_{3}$, the Ki values are generally poor. There was no significant rule about different substituents in the $R_{1}, R_{2}$ and $R_{3}$ 
positions, regarding the MAO-B inhibition activity. Perhaps the steric hindrance played a key role in the selectivity of MAO-B inhibition.

The MAO-B inhibitory activity of the test compounds was determined by a fluorometric method with a commercial kit procedure [18]. An example of the data obtained for the $\mathrm{IC}_{50}$ determinations is illustrated for PX-D-P4 (Figure 5). The Ki values are obtained from the measured $\mathrm{IC}_{50}$ values, which were calculated by the Cheng-Prusoff equation [19].

\subsection{Cell Cytotoxicity}

Human neuroblastoma SH-SY5Y cell line was chosen for testing the cell cytotoxicity, because it had been used as an in vitro model of neuronal function and differentiation. SH-SY5Y cells were exposed to relatively high concentrations of test compounds, in order to observe the cell cytotoxicity. The antiproliferative activity results all test compounds are shown in Figure 6 in the form of mean \pm SD. The $\%$ cell viability values were more than $88 \%$. The results indicate that cytotoxicity of test compounds to SH-SY5Y cells is very low. Moreover, test compounds with different structure have little discrepancy in antiproliferative activities.

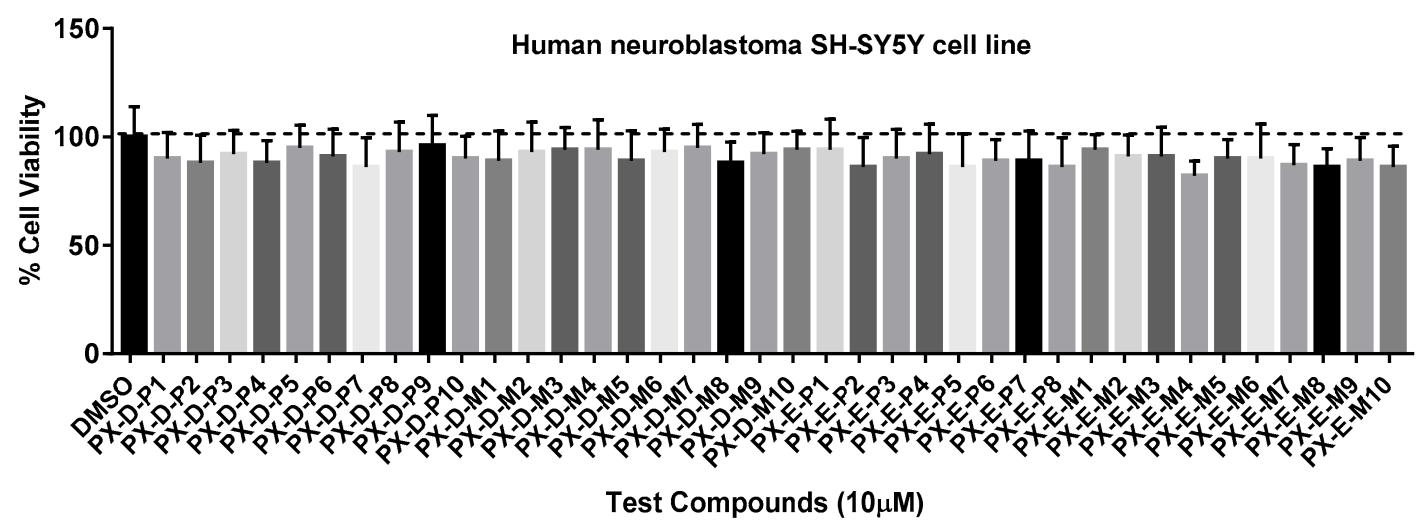

Figure 6. Cytotoxicity of test compounds against human neuroblastoma SH-SY5Y cell line was measured by the MTT method after $24 \mathrm{~h}$. The values are displayed as mean $\pm \mathrm{SD}$.

\subsection{Pharmacokinetics and Brain Distribution of PX-D-P6 and PX-E-P8}

According to the biological data of A2AR affinities and MAO-B inhibitory potencies, PX-D-P6 and PX-E-P8 were chosen for further efficacy studies in vivo. Pharmacokinetics and brain distribution were studied as a matter of priority in order to observe their absorption, elimination and brain penetration. The primary pharmacokinetic parameter results of PX-D-P6 and PX-E-P8 are summarized in Table 2.

Table 2. The main pharmacokinetic parameters after i.p. administration of $50 \mathrm{mg} / \mathrm{kg}$ dose in rats $(n=6)$.

\begin{tabular}{ccc}
\hline Parameters & PX-D-P6 & PX-E-P8 \\
\hline $\mathrm{T}_{\max }(\mathrm{h})$ & $0.51 \pm 0.15$ & $0.45 \pm 0.21$ \\
$\mathrm{C}_{\max }(\mathrm{ng} / \mathrm{mL})$ & $2112.6 \pm 508.4$ & $1642.1 \pm 435.9$ \\
$\mathrm{t}_{1 / 2}(\mathrm{~h})$ & $4.51 \pm 0.61$ & $3.27 \pm 0.39$ \\
$\mathrm{AUC} \rightarrow \mathrm{t}(\mathrm{ng} / \mathrm{mL} \cdot \mathrm{h})$ & $30526.2 \pm 1206.7$ & $15564.2 \pm 1537.4$ \\
$\mathrm{CL}(\mathrm{L} / \mathrm{h} / \mathrm{kg})$ & $5.47 \pm 1.23$ & $10.28 \pm 2.19$ \\
\hline
\end{tabular}

The $\mathrm{T}_{\max }$ (time of peak plasma concentration) after i.p. administration was $0.51 \mathrm{~h}$ and $0.48 \mathrm{~h}$ for compounds PX-D-P6 and PX-E-P8, respectively. The $\mathrm{t}_{1 / 2}$ (half-life) was $4.51 \mathrm{~h}$ and $3.27 \mathrm{~h}$ for PX-D-P6 and PX-E-P8, respectively. The results that plasma and brain assays for PX-D-P6 and PX-E-P8 at $1 \mathrm{~h}$ after i.p. $50 \mathrm{mg} / \mathrm{kg}$ dosing in rats are shown in Table 3. Compounds PX-D-P6 and PX-E-P8 both displayed the capacity to cross the blood-brain barrier (brain/plasma ratio $=1.14$ and 0.97 for 
PX-D-P6 and PX-E-P8, respectively), which is an important property for the treatment of Parkinson's disease. Compared to PX-E-P8, compound PX-D-P6 had better pharmacokinetic parameters and brain penetration.

Table 3. Plasma and brain assays for PX-D-P6 and PX-E-P8 at $1 \mathrm{~h}$ after i.p. $50 \mathrm{mg} / \mathrm{kg}$ dose in rats $(n=6)$.

\begin{tabular}{cccc}
\hline Compound & Plasma $(\mathbf{n g} / \mathrm{mL})$ & Brain $(\mathbf{n g} / \mathrm{g})$ & B/P Ratio \\
\hline PX-D-P6 & $1126 \pm 207$ & $1289 \pm 132$ & 1.14 \\
PX-E-P8 & $915 \pm 231$ & $887 \pm 113$ & 0.97 \\
\hline
\end{tabular}

\subsection{Haloperidol Induced Catalepsy Study}

Haloperidol blocks the nigrostriatal dopamine transmission leading to symptoms such as catalepsy and muscular rigidity, making it a robust animal model for screening of antiparkinsonian drugs [20]. Selective antagonists of A2AR were reported to resist the catalepsy induced by haloperidol [21,22]. In the chronic haloperidol model, treatment with different doses of PX-D-P6 and PX-E-P8 (5, 15 and $50 \mathrm{mg} / \mathrm{kg}$ ) was administered. The effects of PX-D-P6 (A) and PX-E-P8 (B) on haloperidol-induced catalepsy in rats are displayed in Figure 7. On the whole, the effect of both PX-D-P6 and PX-E-P8 was a significant reduction in catalepsy with different doses. Figure 7A shows that there was a dose-dependent relationship between compound PX-D-P6 and reduction in catalepsy, and PX-D-P6 displayed significant anti-catalepsy ability at a dose of $50 \mathrm{mg} / \mathrm{kg}$. Only with high dose, could compound PX-E-P8 display significant anti-catalepsy ability, and it had slight effects at low dose (Figure 7B).
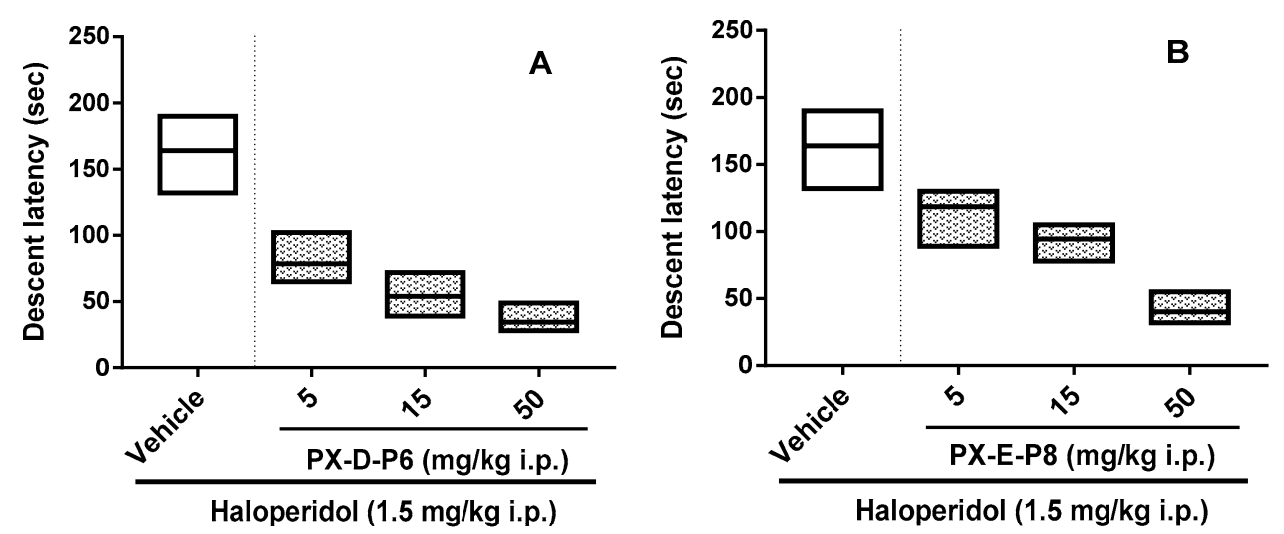

Figure 7. Effects of PX-D-P6 (A) and PX-E-P8 (B) on haloperidol-induced catalepsy in rats with different concentrations $(5 \mathrm{mg} / \mathrm{kg}, 15 \mathrm{mg} / \mathrm{kg}, 50 \mathrm{mg} / \mathrm{kg}$ ). Each column indicates the median and interquartile ranges, and the number of rats used was six, $p<0.05$ (Bonferroni's test), compared with the vehicle-treated group.

The anti-catalepsy efficacy between PX-D-P6 and PX-E-P8 was different at low dose. The reason could derive from the differences in biological data (PX-D-P6: Ki hA2AR, 330 nM; Ki hMAO-B, 290 nM; PX-E-P8: Ki hA2AR, 850 nM; Ki hMAO-B, $630 \mathrm{nM}$ ), and from the different B/P ratios (PX-D-P6: 1.14; PX-E-P8: 0.97). These differences resulted in low brain concentration of PX-E-P8, so that the anti-catalepsy efficacy was unsatisfactory with a low dose.

Comparing their structures, PX-E-P8 has a larger electron withdrawing effect and steric hindrance, which could reduce the affinity with A2A receptor and increase the difficulty in penetrating the blood brain barrier.

Comparing with other reported dual-acting compounds for Parkinson's disease, The anti-catalepsy efficacy of compounds PX-D-P6 and PX-E-P8 is slightly better than that of compound $\mathbf{1 7 f}$ reported by Rivara in 2013 [18]. In this study, the result was that "compound 17f 
significantly antagonized haloperidol-induced catalepsy at doses of 30 and $100 \mathrm{mg} / \mathrm{kg}$, while it was inactive at a dose of $10 \mathrm{mg} / \mathrm{kg}^{\prime \prime}$.

\section{Materials and Methods}

\subsection{Materials}

All organic chemicals were available commercially and used without further purification. The common reagents were purchased from Sinopharm Chemical Reagent Corporation (Shanghai, China), except for monoamine oxidase B (Sigma-Aldrich Corporation, St. Louis, Missouri, USA), and [3H]ZM241385 (Biotrend, Cologne, Germany). Thin layer chromatography was performed on silica gel plates (F254, $0.2 \mathrm{~mm}$ thick). The IR spectra were assayed on a Nicolet NEXUS 670 FT-IR Spectrometer in KBr pellets (Thermo Scientific Corporation, Waltham, Massachusetts, USA). Mass spectra were recorded with a Bruker Esquire HCT plus mass spectrometer in the positive ion mode (Bruker Corporation, Ettlingen, Germany). ${ }^{1} \mathrm{H}$ nuclear magnetic resonance spectra were recorded on a Bruker AVANCE III $600 \mathrm{MHz}$ NMR spectrometer (Bruker Corporation, Ettlingen, Germany). The splitting patterns of NMR spectra were designated as follows: s: singlet; d: doublet; t: triplet; m: multiplet; J: coupling constants. Elemental analysis for $\mathrm{C}, \mathrm{H}$ and $\mathrm{N}$ was performed using a Flash EA 1112 Elemental Analyzer (Thermo Scientific Corporation) and were found within $\pm 0.5 \%$ of the theoretical values. The bound radioactivity for A2AR binding experiments was assayed by a MicroBeta counter (PerkinElmer Corporation, Fremont, California, USA). The luminescent signal for MAO-B activity assay was read at a GloMax 96 Microplate Luminometer (Promega Corporation, Madison, Wisconsin, USA).

\subsection{Synthesis of PX-D and PX-E Analogues}

The general route design for the synthesis of phenylxanthine derivatives of the PX-D and PX-E series was shown in Scheme 1. For details of the synthesis of PX-D-P4, PX-D-P5, PX-D-P9, PX-D-P10, PX-D-M4, PX-D-M55, PX-D-M9, PX-D-M10, PX-E-P4, PX-E-P8, PX-E-M5, PX-E-M10, see our previously reported analogues $[10,11]$. The other compounds had been reported in two earlier articles $[10,11]$. Structural characterization data (FT-IR, ${ }^{1} \mathrm{H}-\mathrm{NMR}$, mass spectra and elemental analysis) of all the synthesized PX-D and PX-E analogues was as follows:

3-Chloro-N-(4-(1,3-dimethyl-2,6-dioxo-2,3,6,7-tetrahydro-1H-purin-8-yl)phenyl)benzamide (PX-D-P4). Dark brown solid, Yield: $58.2 \%$; $\mathrm{mp}>300{ }^{\circ} \mathrm{C}$; IR $\left(\mathrm{cm}^{-1}\right): v_{\mathrm{N}-\mathrm{H}}$ : 3289.12, 3175.20; $v_{\mathrm{C}=\mathrm{O}}$ : 1697.67, 1678.72, 1662.48; ${ }^{1} \mathrm{H}-\mathrm{NMR}\left(\mathrm{DMSO}_{-} \mathrm{d}_{6}\right): 3.27\left(\mathrm{~s}, 3 \mathrm{H}, \mathrm{N}-\mathrm{CH}_{3}\right), 3.51\left(\mathrm{~s}, 3 \mathrm{H}, \mathrm{N}-\mathrm{CH}_{3}\right), 7.60(\mathrm{t}, 1 \mathrm{H}, J=7.8 \mathrm{~Hz}$, $5^{\prime \prime}$-NHCO-PhH), 7.695 (d, 1H, J = 8.4 Hz, CONH-PhH), $7.93\left(\mathrm{~m}, 3 \mathrm{H}, \mathrm{CONH}-\mathrm{PhH}+4^{\prime \prime}, 6^{\prime \prime}-\mathrm{NHCO}-\mathrm{PhH}\right)$, $8.02\left(\mathrm{~s}, 1 \mathrm{H}, 2^{\prime \prime}-\mathrm{NHCO}-\mathrm{PhH}\right), 8.14(\mathrm{~d}, 2 \mathrm{H}, J=8.4 \mathrm{~Hz}, \mathrm{CONH}-\mathrm{PhH} \times 2), 10.56(\mathrm{~s}, 1 \mathrm{H}, \mathrm{CONH}), 13.73(\mathrm{~s}$, $1 \mathrm{H}$, xanthineH). EI-MS: $410.1[\mathrm{M}+\mathrm{H}]^{+}$. Chemical Formula: $\mathrm{C}_{20} \mathrm{H}_{16} \mathrm{ClN}_{5} \mathrm{O}_{3}$, Calcd. For: $\mathrm{C}, 58.61 ; \mathrm{H}$, 3.94; N, 17.09. Found: C, 58.52; H, 3.95; N, 17.06.

N-(4-(1,3-Dimethyl-2,6-dioxo-2,3,6,7-tetrahydro-1H-purin-8-yl)phenyl)-3,4-dimethoxybenzamide (PX-D-P5). Dark brown solid, Yield: $49.8 \%$; $\mathrm{mp}>300{ }^{\circ} \mathrm{C}$; IR $\left(\mathrm{cm}^{-1}\right): v_{\mathrm{N}-\mathrm{H}}: 3464.56,3149.94 ; v_{\mathrm{C}=\mathrm{O}}: 1678.84$, 1670.30, 1662.19. ${ }^{1} \mathrm{H}-\mathrm{NMR}\left(\mathrm{DMSO}-\mathrm{d}_{6}\right): 3.27\left(\mathrm{~s}, 3 \mathrm{H}, \mathrm{N}-\mathrm{CH}_{3}\right), 3.51\left(\mathrm{~s}, 3 \mathrm{H}, \mathrm{N}-\mathrm{CH}_{3}\right), 3.85\left(\mathrm{~s}, 6 \mathrm{H}, \mathrm{OCH}_{3} \times 2\right)$, $7.11(\mathrm{~d}, 1 \mathrm{H}, J=8.4 \mathrm{~Hz}, \mathrm{CONH}-\mathrm{PhH}), 7.54(\mathrm{~d}, 1 \mathrm{H}, J=7.8 \mathrm{~Hz}, \mathrm{NHCO}-\mathrm{PhH}), 7.65$ (s, 1H, 2'-NHCO-PhH), $7.86(\mathrm{~d}, 1 \mathrm{H}, J=7.8 \mathrm{~Hz}, \mathrm{NHCO}-\mathrm{PhH}), 7.92(\mathrm{~m}, 1 \mathrm{H}, \mathrm{CONH}-\mathrm{PhH}), 8.13(\mathrm{~m}, 2 \mathrm{H}, \mathrm{CONH}-\mathrm{PhH} \times 2), 10.29(\mathrm{~s}$, $1 \mathrm{H}, \mathrm{CONH}), 13.73\left(\mathrm{~s}, 1 \mathrm{H}\right.$, xanthineH). EI-MS: $436.0[\mathrm{M}+\mathrm{H}]^{+}$. Chemical Formula: $\mathrm{C}_{22} \mathrm{H}_{21} \mathrm{~N}_{5} \mathrm{O}_{5}$; Calcd. For: C, 60.68; H, 4.86; N, 16.08; Found: C, 60.67; H, 4.81; N, 16.11 .

3-Chloro-N-(4-(1,3,7-trimethyl-2,6-dioxo-2,3,6,7-tetrahydro-1H-purin-8-yl)phenyl)benzamide (PX-D-P9). Dark brown solid, Yield: 53.4\%; $\mathrm{mp}>300{ }^{\circ} \mathrm{C}$; IR $\left(\mathrm{cm}^{-1}\right): v_{\mathrm{N}-\mathrm{H}}: 3381.99 ; v_{\mathrm{C}=\mathrm{O}}: 1666.59,1649.87$. ${ }^{1} \mathrm{H}-\mathrm{NMR}\left(\mathrm{DMSO}-\mathrm{d}_{6}\right): 3.27\left(\mathrm{~s}, 3 \mathrm{H}, \mathrm{N}-\mathrm{CH}_{3}\right), 3.38\left(\mathrm{~s}, 3 \mathrm{H}, \mathrm{N}-\mathrm{CH}_{3}\right), 4.03\left(\mathrm{~s}, 3 \mathrm{H}, \mathrm{N}-\mathrm{CH}_{3}\right), 7.62(\mathrm{t}, 1 \mathrm{H}$, $\left.J=7.8 \mathrm{~Hz}, 5^{\prime}-\mathrm{NHCO}-\mathrm{PhH}\right), 7.71(\mathrm{~d}, 1 \mathrm{H}, J=6.6 \mathrm{~Hz}, \mathrm{NHCO}-\mathrm{PhH}), 7.85(\mathrm{~d}, 2 \mathrm{H}, J=9 \mathrm{~Hz}, \mathrm{CONH}-\mathrm{PhH} \times 2)$, $7.95(\mathrm{~d}, 1 \mathrm{H}, J=7.8 \mathrm{~Hz}, \mathrm{NHCO}-\mathrm{PhH}), 8.00(\mathrm{~d}, 2 \mathrm{H}, J=9 \mathrm{~Hz}, \mathrm{CONH}-\mathrm{PhH} \times 2), 8.04\left(\mathrm{~s}, 1 \mathrm{H}, 2^{\prime}-\mathrm{NHCO}-\mathrm{PhH}\right)$, 
10.61 (s, 1H, CONH). EI-MS: $424.0[\mathrm{M}+\mathrm{H}]^{+}$. Chemical Formula: $\mathrm{C}_{21} \mathrm{H}_{18} \mathrm{ClN}_{5} \mathrm{O}_{3}$; Calcd. For: C, 59.51; $\mathrm{H}, 4.28 ; \mathrm{N}, 16.52$; Found: $\mathrm{C}, 59.54 ; \mathrm{H}, 4.30 ; \mathrm{N}, 16.56$.

3,4-Dimethoxy-N-(4-(1,3,7-trimethyl-2,6-dioxo-2,3,6,7-tetrahydro-1H-purin-8-yl)phenyl)benzamide (PX-D-P10). Dark brown solid, Yield: $47.5 \% ; \mathrm{mp}>300{ }^{\circ} \mathrm{C}$; IR $\left(\mathrm{cm}^{-1}\right): v_{\mathrm{N}-\mathrm{H}}: 3527.37,3204.87 ; v_{\mathrm{C}=\mathrm{O}}$ : 1701.45, 1688.34, 1658.48. ${ }^{1} \mathrm{H}-\mathrm{NMR}\left(\mathrm{DMSO}_{6}\right): 3.28\left(\mathrm{~s}, 3 \mathrm{H}, \mathrm{N}-\mathrm{CH}_{3}\right), 3.35\left(\mathrm{~s}, 3 \mathrm{H}, \mathrm{N}-\mathrm{CH}_{3}\right), 3.38(\mathrm{~s}, 3 \mathrm{H}$, $\left.\mathrm{N}-\mathrm{CH}_{3}\right), 3.52\left(\mathrm{~s}, 3 \mathrm{H},-\mathrm{OCH}_{3}\right), 3.83\left(\mathrm{~s}, 3 \mathrm{H},-\mathrm{OCH}_{3}\right), 7.04(\mathrm{~d}, 2 \mathrm{H}, J=8.4 \mathrm{~Hz}, \mathrm{CONH}-\mathrm{PhH} \times 2), 7.22(\mathrm{~d}, 1 \mathrm{H}$, $J=7.8 \mathrm{~Hz}, \mathrm{NHCO}-\mathrm{PhH}), 7.46\left(\mathrm{~s}, 1 \mathrm{H}, 2^{\prime \prime}-\mathrm{NHCO}-\mathrm{PhH}\right), 7.54(\mathrm{~d}, 1 \mathrm{H}, J=7.8 \mathrm{~Hz}, \mathrm{NHCO}-\mathrm{PhH}), 7.84(\mathrm{~d}$, $2 \mathrm{H}, J=8.4 \mathrm{~Hz}, \mathrm{CONH}-\mathrm{PhH} \times 2), 10.33(\mathrm{~s}, 1 \mathrm{H}, \mathrm{CONH})$. EI-MS: $450.0[\mathrm{M}+\mathrm{H}]^{+}$. Chemical Formula: $\mathrm{C}_{23} \mathrm{H}_{23} \mathrm{~N}_{5} \mathrm{O}_{5}$; Calcd. For: C, 61.46; H, 5.16; N, 15.58; Found: C, 61.49; H, 5.13; N, 15.52 .

3-Chloro-N-(3-(1,3-dimethyl-2,6-dioxo-2,3,6,7-tetrahydro-1H-purin-8-yl)phenyl)benzamide (PX-D-M4). Dark brown solid, Yield: $55.6 \%$; $\mathrm{mp}>300{ }^{\circ} \mathrm{C}$; IR $\left(\mathrm{cm}^{-1}\right): v_{\mathrm{N}-\mathrm{H}}$ : 3268.69; $v_{\mathrm{C}=\mathrm{O}}: 1701.17,1638.11,1659.97$. ${ }^{1} \mathrm{H}-\mathrm{NMR}$ (DMSO-d $\left.\mathrm{D}_{6}\right): 3.25\left(\mathrm{~s}, 3 \mathrm{H}, \mathrm{N}-\mathrm{CH}_{3}\right), 3.45\left(\mathrm{~s}, 3 \mathrm{H}, \mathrm{N}-\mathrm{CH}_{3}\right), 7.355(\mathrm{~d}, 2 \mathrm{H}, J=7.8 \mathrm{~Hz}$, CONH-PhH $\times 2), 7.486\left(\mathrm{t}, 1 \mathrm{H}, J=15.6 \mathrm{~Hz}, 5^{\prime \prime}-\mathrm{NHCO}-\mathrm{PhH}\right), 7.886(\mathrm{~m}, 2 \mathrm{H}, \mathrm{CONH}-\mathrm{PhH} \times 2), 7.921(\mathrm{~d}$, $\left.2 \mathrm{H}, J=15.6 \mathrm{~Hz}, 4^{\prime}, 6^{\prime}-\mathrm{NHCO}-\mathrm{PhH}\right), 8.568$ (s, 1H, 2'-NHCO-PhH), 10.29 (s, 1H, CONH), 13.90 (s, 1H, xanthineH). EI-MS: 409.8 [M + H] ${ }^{+}$. Chemical Formula: $\mathrm{C}_{20} \mathrm{H}_{16} \mathrm{ClN}_{5} \mathrm{O}_{3}$, Calcd. For: C, 58.61; H, 3.94; N, 17.09; Found: C, 58.57; H, 3.90; N, 17.12 .

N-(3-(1,3-Dimethyl-2,6-dioxo-2,3,6,7-tetrahydro-1H-purin-8-yl)phenyl)-3,4-dimethoxybenzamide (PX-D-M5). Dark brown solid, Yield: 50.9\%; $\mathrm{mp}>300{ }^{\circ} \mathrm{C}$; IR $\left(\mathrm{cm}^{-1}\right): v_{\mathrm{N}-\mathrm{H}}: 3502.43 ; v_{\mathrm{C}=\mathrm{O}}: 1701.42,1674.42$, 1664.52. ${ }^{1} \mathrm{H}-\mathrm{NMR}\left(\mathrm{DMSO}_{\mathrm{d}}\right): 3.28\left(\mathrm{~s}, 3 \mathrm{H}, \mathrm{N}-\mathrm{CH}_{3}\right), 3.39\left(\mathrm{~s}, 3 \mathrm{H}, \mathrm{N}-\mathrm{CH}_{3}\right), 3.53\left(\mathrm{~s}, 3 \mathrm{H},-\mathrm{OCH}_{3}\right), 3.86(\mathrm{~s}$, $\left.3 \mathrm{H},-\mathrm{OCH}_{3}\right), 7.11(\mathrm{~d}, 2 \mathrm{H}, \mathrm{J}=8.4 \mathrm{~Hz}, \mathrm{CONH}-\mathrm{PhH}), 7.50(\mathrm{t}, 1 \mathrm{H}, J=7.8 \mathrm{~Hz}, \mathrm{CONH}-\mathrm{PhH}), 7.670(\mathrm{~s}, 1 \mathrm{H}$, CONH-PhH), $7.89(\mathrm{~m}, 2 \mathrm{H}, \mathrm{NHCO}-\mathrm{PhH} \times 2), 8.52\left(\mathrm{~s}, 1 \mathrm{H}, 2^{\prime}-\mathrm{NHCO}-\mathrm{PhH}\right), 10.28(\mathrm{~s}, 1 \mathrm{H}, \mathrm{CONH}), 13.91$ (s, $1 \mathrm{H}$, xanthineH). EI-MS: $436.0[\mathrm{M}+\mathrm{H}]^{+}$. Chemical Formula: $\mathrm{C}_{22} \mathrm{H}_{21} \mathrm{~N}_{5} \mathrm{O}_{5}$; Calcd. For: $\mathrm{C}, 60.68 ; \mathrm{H}$, 4.86; N, 16.08; Found: C, 60.65; H, 4.81; N, 16.09.

3-Chloro-N-(3-(1,3,7-trimethyl-2,6-dioxo-2,3,6,7-tetrahydro-1H-purin-8-yl)phenyl)benzamide (PX-D-M9). Dark brown solid, Yield: $56.0 \% ; \mathrm{mp}>300{ }^{\circ} \mathrm{C}$; IR $\left(\mathrm{cm}^{-1}\right): v_{\mathrm{N}-\mathrm{H}}: 3248.75,3156.49 ; v_{\mathrm{C}=\mathrm{O}}: 1704.37$, 1679.88, 1675.25. ${ }^{1} \mathrm{H}-\mathrm{NMR}\left(\mathrm{DMSO}_{6}\right): 3.24\left(\mathrm{~s}, 3 \mathrm{H}, \mathrm{N}-\mathrm{CH}_{3}\right), 3.46\left(\mathrm{~s}, 3 \mathrm{H}, \mathrm{N}-\mathrm{CH}_{3}\right), 4.02\left(\mathrm{~s}, 3 \mathrm{H}, \mathrm{N}-\mathrm{CH}_{3}\right)$, $7.54\left(\mathrm{~d}, 2 \mathrm{H}, J=6.6 \mathrm{~Hz}, 4^{\prime}, 6^{\prime}-\mathrm{NHCO}-\mathrm{PhH} \times 2\right), 7.57(\mathrm{t}, 1 \mathrm{H}, J=7.8 \mathrm{~Hz}, \mathrm{CONH}-\mathrm{PhH}), 7.67(\mathrm{~d}, 1 \mathrm{H}$, $J=7.8, \mathrm{CONH}-\mathrm{PhH}), 7.93(\mathrm{~d}, 1 \mathrm{H}, J=8.4 \mathrm{~Hz}, \mathrm{CONH}-\mathrm{PhH}), 7.96\left(\mathrm{t}, 1 \mathrm{H}, J=6.6 \mathrm{~Hz}, 5^{\prime}-\mathrm{NHCO}-\mathrm{PhH}\right)$, 8.03 (s, 1H, CONH-PhH), 8.20 (s, 1H, 2'-NHCO-PhH), 10.55 (s, 1H, CONH). EI-MS: $424.2[\mathrm{M}+\mathrm{H}]^{+}$. Chemical Formula: $\mathrm{C}_{21} \mathrm{H}_{18} \mathrm{ClN}_{5} \mathrm{O}_{3}$; Calcd. For: $\mathrm{C}, 59.51 ; \mathrm{H}, 4.28 ; \mathrm{Cl}, 8.36 ; \mathrm{N}, 16.52$; Found: $\mathrm{C}, 59.45 ; \mathrm{H}$, 4.30; N, 16.55 .

3,4-Dimethoxy-N-(3-(1,3,7-trimethyl-2,6-dioxo-2,3,6,7-tetrahydro-1H-purin-8-yl)phenyl)benzamide

(PX-D-M10). Dark brown solid, Yield: $56.3 \% ; \mathrm{mp}>300^{\circ} \mathrm{C}$; IR $\left(\mathrm{cm}^{-1}\right): v_{\mathrm{N}-\mathrm{H}}: 3505.78 ; v_{\mathrm{C}=\mathrm{O}}: 1697.61$, 1657.12. ${ }^{1} \mathrm{H}-\mathrm{NMR}\left(\mathrm{DMSO}_{\mathrm{d}}\right)$ ) $3.27\left(\mathrm{~s}, 3 \mathrm{H}, \mathrm{N}-\mathrm{CH}_{3}\right), 3.49\left(\mathrm{~s}, 3 \mathrm{H}, \mathrm{N}-\mathrm{CH}_{3}\right), 3.85\left(\mathrm{~s}, 3 \mathrm{H}, \mathrm{N}-\mathrm{CH}_{3}\right), 3.86(\mathrm{~s}$, $\left.3 \mathrm{H},-\mathrm{OCH}_{3}\right), 4.04\left(\mathrm{~s}, 3 \mathrm{H},-\mathrm{OCH}_{3}\right), 7.11(\mathrm{~s}, 1 \mathrm{H}, \mathrm{PhH}), 7.54(\mathrm{~m}, 2 \mathrm{H}, \mathrm{PhH}), 7.56(\mathrm{~m}, 1 \mathrm{H}, \mathrm{PhH}), 7.66(\mathrm{~d}$, $1 \mathrm{H}, J=7.8 \mathrm{~Hz}, \mathrm{NHCO}-\mathrm{PhH}), 7.92(\mathrm{~d}, 1 \mathrm{H}, J=7.8 \mathrm{~Hz}, \mathrm{NHCO}-\mathrm{PhH}), 8.23\left(\mathrm{~s}, 1 \mathrm{H}, 2^{\prime}-\mathrm{NHCO}-\mathrm{PhH}\right), 10.43$ (s, $1 \mathrm{H}, \mathrm{CONH})$. EI-MS: $450.0[\mathrm{M}+\mathrm{H}]^{+}$. Chemical Formula: $\mathrm{C}_{23} \mathrm{H}_{23} \mathrm{~N}_{5} \mathrm{O}_{5}$, Calcd. For: $\mathrm{C}, 61.46 ; \mathrm{H}, 5.16 ; \mathrm{N}$, 15.58; Found: C, 61.37; H, 5.13; N, 15.64

(E)-3-(3-Chlorophenyl)-N-(4-(1,3-dimethyl-2,6-dioxo-2,3,6,7-tetrahydro-1H-purin-8-yl)phenyl)acrylamide

(PX-E-P4). Dark brown solid, Yield: $46.5 \%$; mp $>300{ }^{\circ} \mathrm{C}$; IR $\left(\mathrm{cm}^{-1}\right): v_{\mathrm{N}-\mathrm{H}}: 3467.64,3126.09 . v_{\mathrm{C}=\mathrm{O}}$ : 1687.37, 1678.34, 1673.89. ${ }^{1} \mathrm{H}-\mathrm{NMR}\left(\mathrm{DMSO}_{6}\right)$ : $3.27\left(\mathrm{~s}, 3 \mathrm{H}, \mathrm{N}_{-} \mathrm{CH}_{3}\right), 3.51\left(\mathrm{~s}, 3 \mathrm{H}, \mathrm{N}_{-} \mathrm{CH}_{3}\right), 6.91(\mathrm{t}, 1 \mathrm{H}$, $\left.J=15.6 \mathrm{~Hz}, 5^{\prime}-\mathrm{PhH}\right), 7.62\left(\mathrm{~d}, 2 \mathrm{H}, J=15.6 \mathrm{~Hz}, 4^{\prime}, 6^{\prime}-\mathrm{PhH}\right), 7.49(\mathrm{~m}, 2 \mathrm{H},=\mathrm{CH} \times 2), 7.71(\mathrm{~d}, 2 \mathrm{H}, J=9.0 \mathrm{~Hz}$, CONH-PhH $\times 2), 7.83\left(\mathrm{~s}, 1 \mathrm{H}, 2^{\prime}-\mathrm{PhH}\right), 8.11(\mathrm{~d}, 2 \mathrm{H}, J=8.4 \mathrm{~Hz}, \mathrm{CONH}-\mathrm{PhH} \times 2), 10.47(\mathrm{~s}, 1 \mathrm{H}, \mathrm{CONH})$, 13.73 (s, 1H, xanthineH). EI-MS: $436.1[\mathrm{M}+\mathrm{H}]^{+}$. Chemical Formula: $\mathrm{C}_{22} \mathrm{H}_{18} \mathrm{ClN}_{5} \mathrm{O}_{3}$; Calcd. For: $\mathrm{C}$, 60.62; H, 4.16; N, 16.07; Found: C, 60.51; H, 4.19; N, 16.02

(E)-3-(3-Chlorophenyl)-N-(4-(1,3,7-trimethyl-2,6-dioxo-2,3,6,7-tetrahydro-1H-purin-8-yl)phenyl)acrylamide (PX-E-P8). Dark brown solid, Yield: $42.3 \%$; $\mathrm{mp}>300{ }^{\circ} \mathrm{C}$; IR $\left(\mathrm{cm}^{-1}\right): v_{\mathrm{N}-\mathrm{H}}: 3508.03 ; v_{\mathrm{C}=\mathrm{O}}: 1686.59$, 
1644.26. ${ }^{1} \mathrm{H}-\mathrm{NMR}\left(\mathrm{DMSO}_{6} \mathrm{~d}_{6}\right): 3.26\left(\mathrm{~s}, 3 \mathrm{H}, \mathrm{N}-\mathrm{CH}_{3}\right), 3.48\left(\mathrm{~s}, 3 \mathrm{H}, \mathrm{N}-\mathrm{CH}_{3}\right), 4.028\left(\mathrm{~s}, 3 \mathrm{H}, \mathrm{N}-\mathrm{CH}_{3}\right), 6.93(\mathrm{t}$, $\left.1 \mathrm{H}, J=15.6 \mathrm{~Hz}, 5^{\prime}-\mathrm{PhH}\right), 7.50(\mathrm{~m}, 2 \mathrm{H},=\mathrm{CH} \times 2), 7.62(\mathrm{~d}, 2 \mathrm{H}, J=8.4 \mathrm{~Hz}, \mathrm{CONH}-\mathrm{PhH} \times 2), 7.73(\mathrm{~s}$, $\left.1 \mathrm{H}, 2^{\prime}-\mathrm{PhH}\right), 7.83(\mathrm{~d}, 2 \mathrm{H}, J=8.4 \mathrm{~Hz}, \mathrm{CONH}-\mathrm{PhH} \times 2), 7.89\left(\mathrm{~d}, 2 \mathrm{H}, J=9.0 \mathrm{~Hz}, 4^{\prime}, 6^{\prime}-\mathrm{PhH}\right), 10.54(\mathrm{~s}, 1 \mathrm{H}$, CONH). EI-MS: $450.1[\mathrm{M}+\mathrm{H}]^{+}$. Chemical Formula: $\mathrm{C}_{23} \mathrm{H}_{20} \mathrm{ClN}_{5} \mathrm{O}_{3}$; Calcd. For: $\mathrm{C}, 61.40 ; \mathrm{H}, 4.48 ; \mathrm{N}$, 15.57; Found: C, 61.51; H, 4.47; N, 15.63.

(E)-3-(3,4-Dimethoxyphenyl)-N-(4-(1,3-dimethyl-2,6-dioxo-2,3,6,7-tetrahydro-1H-purin-8-yl)phenyl)-acrylamide (PX-E-M5). Dark brown solid, Yield: $40.7 \%$; mp > $300{ }^{\circ} \mathrm{C}$; IR $\left(\mathrm{cm}^{-1}\right): v_{\mathrm{N}-\mathrm{H}}: 3340.88,3305.87 ; v_{\mathrm{C}=\mathrm{O}}$ : 1697.77, 1650.21, 1630.65. ${ }^{1} \mathrm{H}-\mathrm{NMR}\left(\mathrm{DMSO}_{6}\right): 3.28\left(\mathrm{~s}, 3 \mathrm{H}, \mathrm{N}-\mathrm{CH}_{3}\right), 3.52\left(\mathrm{~s}, 3 \mathrm{H}, \mathrm{N}-\mathrm{CH}_{3}\right), 3.81(\mathrm{~s}, 3 \mathrm{H}$, $\left.-\mathrm{OCH}_{3}\right), 3.83\left(\mathrm{~s}, 3 \mathrm{H},-\mathrm{OCH}_{3}\right), 6.74\left(\mathrm{~d}, 1 \mathrm{H}, J=15.6 \mathrm{~Hz}, 6^{\prime}-\mathrm{PhH}\right), 7.57\left(\mathrm{~d}, 1 \mathrm{H}, J=15.6 \mathrm{~Hz}, 5^{\prime}-\mathrm{PhH}\right), 7.04(\mathrm{~d}$, $1 \mathrm{H}, J=8.4 \mathrm{~Hz}, \mathrm{CONH}-\mathrm{PhH}), 7.22(\mathrm{~m}, 2 \mathrm{H},=\mathrm{CH} \times 2), 7.46(\mathrm{t}, 1 \mathrm{H}, J=8.4 \mathrm{~Hz}, \mathrm{CONH}-\mathrm{PhH}), 7.84(\mathrm{~m}$, 2H, CONH-PhH), 8.44 (s, 1H, 2'-PhH), 10.34 (s, 1H, CONH), 13.96 (s, 1H, xanthineH). EI-MS: 462.0 $[\mathrm{M}+\mathrm{H}]^{+}$. Chemical Formula: $\mathrm{C}_{24} \mathrm{H}_{23} \mathrm{~N}_{5} \mathrm{O}_{5}$; Calcd. For: $\mathrm{C}, 62.47 ; \mathrm{H}, 5.02 ; \mathrm{N}, 15.18$; Found: $\mathrm{C}, 62.49 ; \mathrm{H}$, $5.06 ; \mathrm{N}, 15.22$.

(E)-3-(3,4-Dimethoxyphenyl)-N-(4-(1,3,7-trimethyl-2,6-dioxo-2,3,6,7-tetrahydro-1H-purin-8-yl)phenyl)acrylamide (PX-E-M10). Dark brown solid, Yield: 46.3\%; mp $>300{ }^{\circ} \mathrm{C}$; IR $\left(\mathrm{cm}^{-1}\right): v_{\mathrm{N}-\mathrm{H}}$ : 3525.19 , 3283.08; $v_{\mathrm{C}=\mathrm{O}}: 1681.79,1645.73,1625.04 .{ }^{1} \mathrm{H}-\mathrm{NMR}\left(\mathrm{DMSO}_{6}\right)$ : $3.26\left(\mathrm{~s}, 3 \mathrm{H}, \mathrm{N}-\mathrm{CH}_{3}\right), 3.38(\mathrm{~s}, 3 \mathrm{H}$, $\left.\mathrm{N}-\mathrm{CH}_{3}\right), 3.48\left(\mathrm{~s}, 3 \mathrm{H}, \mathrm{N}-\mathrm{CH}_{3}\right), 3.82\left(\mathrm{~s}, 3 \mathrm{H},-\mathrm{OCH}_{3}\right), 4.02\left(\mathrm{~s}, 3 \mathrm{H},-\mathrm{OCH}_{3}\right), 6.72(\mathrm{~d}, 1 \mathrm{H}, J=15.6 \mathrm{~Hz}$, $\left.6^{\prime}-\mathrm{PhH}\right), 7.03(\mathrm{~d}, 1 \mathrm{H}, J=7.4 \mathrm{~Hz}, \mathrm{CONH}-\mathrm{PhH}), 7.19(\mathrm{~d}, 1 \mathrm{H}, J=7.4 \mathrm{~Hz}, \mathrm{CONH}-\mathrm{PhH}), 7.22(\mathrm{~d}, 1 \mathrm{H}$, $J=8.4 \mathrm{~Hz}, \mathrm{COCH}=\mathrm{CH}), 7.51(\mathrm{t}, 1 \mathrm{H}, J=7.4 \mathrm{~Hz}, \mathrm{CONH}-\mathrm{PhH}), 7.53(\mathrm{~d}, 1 \mathrm{H}, J=8.4 \mathrm{~Hz}, \mathrm{COCH}), 7.55(\mathrm{~d}$, $\left.1 \mathrm{H}, J=15.6 \mathrm{~Hz}, 5^{\prime}-\mathrm{PhH}\right), 7.87$ (s, 1H, CONH-PhH), 8.17 (s, 1H, 2'-PhH), 10.38 (s, 1H, CONH). EI-MS: $476.1[\mathrm{M}+\mathrm{H}]^{+}$. Chemical Formula: $\mathrm{C}_{25} \mathrm{H}_{25} \mathrm{~N}_{5} \mathrm{O}_{5}$; Calcd. For: $\mathrm{C}, 63.15 ; \mathrm{H}, 5.30 ; \mathrm{N}, 14.73$; Found: $\mathrm{C}$, 63.26; H, 5.34; N, 14.69 .

\subsection{Affinity Toward A2AR}

The binding affinity of test compounds was determined using radioligand binding assays. Human A2AR cDNA was stably transfected into HEK-293 cells. Membranes from the transfected cell were used in the interactive capacity of each compound toward the A2AR. Competition binding assay experiments by incubating membranes of $10 \mu \mathrm{g}$ protein with $2 \mathrm{nM}$ [3H]ZM241385 were carried out, with interval concentrations ranging from $0.1 \mathrm{nM}$ to $100 \mu \mathrm{M}$ of test compounds in 96-well filter plates at $4{ }^{\circ} \mathrm{C}$ for $90 \mathrm{~min}$. After incubation experiments, free and bound radioligands were split by filtering and washing. Last, filter-bound radioactivity was counted after addition of $30 \mu \mathrm{L} /$ well of scintillation solution. Nonspecific binding was measured in the presence of $100 \mu \mathrm{M} Z \mathrm{ZM} 241385$. The experiments were carried in duplicate. $\mathrm{IC}_{50}$ values were determined using a nonlinear regression curve fitting by the program GraphPad Prism. The affinities of compounds were calculated by Ki value which was from the $\mathrm{IC}_{50}$ values according as the Cheng-Prusoff equation [19].

\subsection{MAO-B Inhibition Studies}

Inhibitory potency on MAO-B enzyme from recombinant human MAO-B were carried out by a fluorometric method with a commercial kit (Promega, MAO-Glo Assay) [18]. The MAO enzyme incubation experiments were carried with a MAO-B substrate, methyl (S)-2-(6-(2-aminoethoxy) benzo[d]thiazol-2-yl)-4,5-dihydrothiazole-4-carboxylate, which was converted to luciferin methyl ester. Then the "Luciferin Detection Reagent" was added to change the methyl ester derivative to luciferin, stop the MAO-B reaction, and simultaneously produce light. The intensity of light is directly in proportion to MAO-B activity. The assay was carried in a 96-well black opaque microplate in duplicate. The reaction mixture was composed of $12.5 \mu \mathrm{L}$ of MAO-B substrate (a final concentration of $4 \mu \mathrm{M}), 25 \mu \mathrm{L}$ of human MAO-B (1 $\mu \mathrm{g}$ of protein/well), and $12.5 \mu \mathrm{L}$ of test compounds for each well. After $1 \mathrm{~h}$ of incubation at $37^{\circ} \mathrm{C}$, each well added $50 \mu \mathrm{L}$ of "Luciferin Detection Reagent", and incubated an additional $20 \mathrm{~min}$. the luminescent signal of microplate was measured by a luminometer. The signal from reaction of MAO-B enzyme and substrate without inhibitors accounted as the positive control, 
whereas the signal from reaction of MAO-B enzyme and inhibitors in the absence of substrate accounted as the negative control. Compound concentrations of $1 \mu \mathrm{M}$ were tested at first. $\mathrm{IC}_{50}$ values (the half maximal inhibitory concentration) were performed from concentration-response curves, plotted by the GraphPad Prism software. All experiments were performed in duplicate, and data are expressed as mean \pm SD.

\subsection{MTT Cytotoxicity Assay}

The MTT assay method is a colorimetric assay which is based on cell metabolic activity, whereby active cells can reduce MTT [3,[3-(4,5-dimethylthiazol-2-yl)-2,5-diphenyltetrazolium bromide] to its purple formazan which can be measured by spectrophotometry. The antiproliferative activity of cytotoxicity was determined using an MTT assay. The cytotoxic activity of test compounds was assessed in human neuroblastoma SH-SY5Y cell Line. In brief, $1 \times 10^{5}$ cells per well were plated in 96-well culture plates in quadruplicate and incubated for $24 \mathrm{~h}$ in a $\mathrm{CO}_{2}$ incubator. Test compounds were added to the wells with $10 \mu \mathrm{M}$ final concentration. After $24 \mathrm{~h}$ of cells incubation with test compounds, $10 \mu \mathrm{L}$ of MTT labeling reagent was added in each well and then incubated for $4 \mathrm{~h}$ at $37^{\circ} \mathrm{C}$. Following incubation, supernatant was taken away from each well and $100 \mu \mathrm{L}$ of DMSO reagent was added to each well. The absorbance of each well was measured by at $570 \mathrm{~nm}$ after $15 \mathrm{~min}$ delay. The percentage antiproliferative activities were calculated by using the formula: Viability $(\%)=\{[$ A570 (sample absorbance) - (blank absorbance)]/[A570 (control absorbance) - blank absorbance]\} $\times 100$. Cells treated with solvent DMSO were used as the control. The media free of cells was used as the blank sample.

\subsection{Pharmacokinetic Experiments}

Sprague-Dawley rats $(200 \pm 20 \mathrm{~g})$ were obtained from the Laboratory Animal Center of Wenzhou Medical University (Wenzhou, China) to study the pharmacokinetics and tissue distribution studies (TDS) of PX-D-P6 and PX-E-P8 following intraperitoneal injection (i.p.) administration. The experiment procedures and protocols were approved the Animal Care and Use Committee of Wenzhou Medical College and complied with the Guide for the Care and Use of Laboratory Animals. The corresponding ethical approval code was WMU20161025.

The chosen compounds dissolved in suspension formulation ( $2 \%$ Tween 80 -saline) were administered to each rat at a dose of $50 \mathrm{mg} / \mathrm{kg}$. Blood samples $(0.3 \mathrm{~mL})$ were collected from the caudal vein into $1.5 \mathrm{~mL}$ tapered plastic centrifuge tubes (pretreated with $\mathrm{K}_{2}$ EDTA as an anticoagulant) at pre-dose, 0.08, 0.16, 0.25, 0.5, 1, 2, 4, 8, 12, 24 h after i.p. administration. Separately, blood and brain samples were collected at pre-dose and $1 \mathrm{~h}$ for TDS. Blood samples were immediately centrifuged at $3000 \mathrm{~g}$ for $10 \mathrm{~min}$ for isolation of the plasma. Brain samples were homogenized in phosphate buffer saline. $100 \mu \mathrm{L}$ plasma or $200 \mu \mathrm{L}$ brain sample was precipitated with addition of $400 \mu \mathrm{L}$ acetonitrile and vortex mixed for $1 \mathrm{~min}$ and centrifuged at 10,000 $\mathrm{g}$ for $10 \mathrm{~min}$. Finally, $2 \mu \mathrm{L}$ supernatant was injected into UPLC/MS system. Calibration standards samples were prepared with blank rat plasma or brain homogenates. Plasma pharmacokinetic parameters were analyzed by DAS (Drug and Statistics) software (Version 2, Wenzhou Medical University, Wenzhou, China).

\subsection{Pharmacological Potential: Catalepsy}

Catalepsy was measured using a thin metal bar test at $9.0 \mathrm{~cm}$ height [23]. In this test, each rat was injected intraperitoneally by haloperidol $(1.5 \mathrm{mg} / \mathrm{kg})$. Before i.p. administration of vehicle $(2 \%$ Tween 80-saline), PX-D-P6 and PX-E-P8 $(5,15,50 \mathrm{mg} / \mathrm{kg})$, at time $0 \mathrm{~min}$, we tested all rats for successful induction of catalepsy. The length of time (descent latency) it persisted in hanging onto the metal bar was measured for a period of up to $300 \mathrm{~s}$ (maximum score). After this period, the rat was gently removed from the bar. The high bar test was performed $20 \mathrm{~min}$ after the injection of compound. Descent latencies have been presented as median and interquartile ranges. Differences between medians were analyzed by Kruskal-Wallis test, followed by Bonferroni's test. 


\section{Conclusions}

In this work, a series of PX derivatives were synthesized and evaluated for their antiparkinsonian properties. On the whole, PX-D analogues showed slightly better antiparkinsonian properties than PX-E analogues. Of all the compounds, PX-D-P6 and PX-E-P8 were verified as potent A2AR antagonists and MAO-B inhibitors with desirable drug-like properties, including good pharmacokinetic parameters, brain penetration and anti-catalepsy properties. We thus found that PX-D and PX-E analogues are promising candidate dual-acting drugs with antiparkinsonian properties.

Acknowledgments: This work was supported by Wenzhou Municipal Science and Technology Bureau Foundation (Y20150107); Natural Foundation of Zhejiang Province (Y2080697); National Natural Science Foundation of China (81373262); and the Science and Technology Innovation Plan and New-shoot Talents Program for Undergraduates of Zhejiang Province (2016R413003).

Author Contributions: Xuebao Wang and Faqing Ye conceived and designed the experiments; Yong Xu, Kaiqi Wu, Shuangya Chen, Mangsha Hu, Luyao Wang and Yun Ye performed the experiments; Xuebao Wang and Chao Han analyzed the data; Yong $\mathrm{Xu}$, Kaiqi $\mathrm{Wu}$ and Shuangya Chen contributed reagents/materials/analysis tools; Xuebao Wang and Chao Han wrote the paper.

Conflicts of Interest: The authors declare no conflict of interest.

\section{References}

1. Dwolatzky, T. Cognitive Impairment and dementia in Parkinson disease. J. Am. Med. Assoc. 2011, 305, 2231-2234. [CrossRef]

2. Noyce, A.J.; Bestwick, J.P.; Silveira-Moriyama, L.; Hawkes, C.H.; Giovannoni, G.; Lees, A.J.; Schrag, A. Meta-analysis of early nonmotor features and risk factors for Parkinson disease. Ann. Neurol. 2012, 72, 893-901. [CrossRef]

3. Allain, H.; Bentuéferrer, D.; Akwa, Y. Disease-modifying drugs and Parkinson's disease. Prog. Neurobiol. 2008, 84, 25-39. [CrossRef]

4. Villalba, R.M.; Mathai, A.; Smith, Y. Morphological changes of glutamatergic synapses in animal models of Parkinson's disease. Front Neuroanat. 2015, 9, 117. [CrossRef]

5. Politis, M.; Niccolini, F. Serotonin in Parkinson's disease. Behav. Brain. Res. 2014, 277, 136-145. [CrossRef]

6. Shimada, J.; Suzuki, F. Medicinal Chemistry of Adenosine Receptors in the Brain and Periphery. In Adenosine Receptors and Parkinson's Disease; Academic Press: New York, NY, USA, 2000; pp. 31-50.

7. Ciruela, F.; Casado, V.; Rodrigues, R.J.; Lujan, R.; Burgueno, J.; Canals, M.; Borycz, J.; Rebola, N.; Goldberg, S.R.; Mallol, J.; Cortes, A.; et al. Presynaptic control of striatal glutamatergic neurotransmission by adenosine A1-A2A receptor heteromers. J. Neurosci. 2006, 26, 2080-2087. [CrossRef]

8. Schiffmann, S.N.; Fisone, G.; Moresco, R.; Cunha, R.A.; Ferré, S. Adenosine A2A receptors and basal ganglia physiology. Prog. Neurobiol. 2007, 83, 277-292. [CrossRef]

9. Morelli, M.; Carta, A.R.; Jenner, P. Adenosine A2A receptors and Parkinson's disease. Handb. Exp. Pharmacol. 2009, 193, 589-615. [CrossRef]

10. Freitas, M.E.; Fox, S.H. Nondopaminergic treatments for Parkinson's disease, current and future prospects. Neurodegener. Dis. Manag. 2016, 1, 491-512. [CrossRef]

11. A 12-week Randomized Study to Evaluate Oral Istradefylline in Subjects With Moderate to Severe Parkinson's Disease. Available online: https://clinicaltrials.gov/ct2/show/NCT01968031 (accessed on 13 June 2017).

12. Song, B.; Xiao, T.; Qi, X.L.; Li, L.N.; Qin, K.Y.; Nian, S.Y.; Hu, G.X.; Yu, Y.F.; Liang, G.; Ye, F.Q. Design and synthesis of 8-substituted benzamido-phenylxanthine derivatives as MAO-B inhibitors. Bioorg. Med. Chem. Lett. 2012, 22, 1739-1742. [CrossRef]

13. Hu, S.W.; Nian, S.Y.; Qin, K.Y.; Xiao, T.; Li, L.N.; Qi, X.L.; Ye, F.Q.; Liang, G.; Hu, G.X.; He, J.C.; et al. Design, synthesis and inhibitory activities of 8-(substituted styrol-formamido) phenyl-xanthine derivatives on monoamine oxidase B. Chem. Pharm. Bull. 2012, 60, 385-390. [CrossRef]

14. Riederer, P.; Lachenmayer, L.; Laux, G. Clinical applications of MAO-inhibitors. Curr. Med. Chem. 2004, 11, 2033-2043. [CrossRef] 
15. Youdim, M.B.H; Edmondson, D.; Tipton, K.F. The therapeutic potential of monoamine oxidase inhibitors. Nat. Rev. Neurosci. 2006, 7, 295-309. [CrossRef]

16. Chen, J.F.; Steyn, S.; Staal, R.; Petzer, J.P.; Xu, K.; Van der Schyf, C.J.; Castagnoli, K.; Sonsalla, P.K.; Castagnoli, N.; Schwarzschild, M.A. 8-(3-Chlorostyryl)caffeine may attenuate MPTP neurotoxicity through dual actions of monoamine oxidase inhibition and A2A receptor antagonism. J. Biol. Chem. 2002, 277, 36040-36044. [CrossRef]

17. Youdim, M.B.H. Why do we need multifunctional neuroprotective and neurorestorative drugs for Parkinson's and Alzheimer's diseases as disease modifying agents. Rambam. Maimonides. Med. J. 2010, 1, e0011. [CrossRef]

18. Rivara, S.; Piersanti, G.; Bartoccini, F.; Diamantini, G.; Pala, D.; Riccioni, T.; Stasi, M.A.; Cabri, W.; Borsini, F.; Mor, M.; et al. Synthesis of (E)-8-(3-chlorostyryl)caffeine analogues leading to 9-deazaxanthine derivatives as dual $\mathrm{A}_{2 \mathrm{~A}}$ antagonists/MAO-B inhibitors. J. Med. Chem. 2013, 56, 1247-1261. [CrossRef]

19. Lazareno, S.; Birdsall, N.J. Estimation of antagonist $\mathrm{Kb}$ from inhibition curves in functional experiments, alternatives to the Cheng-Prusoff equation. Trends. Pharmacol. Sci. 1993, 14, 237-239. [CrossRef]

20. Duty, S.; Jenner, P. Animal models of Parkinson's disease, a source of novel treatments and clues 468 to the cause of the disease. Brit. J. Pharmacol. 2011, 164, 1357-1391. [CrossRef]

21. Cieślak, M.; Komoszyński, M.; Wojtczak, A. Adenosine $A_{2 A}$ receptors in Parkinson's disease treatment. Purinerg. Signal. 2008, 4, 305-312. [CrossRef]

22. Barodia, S.K.; Mishra, C.B.; Prakash, A.; Senthil Kumar, J.B.; Kumari, N.; Luthra, P.M. 8-(furan-2-yl)-3-phenethylthiazolo [5,4-e] [1,2,4] triazolo [1,5-c] pyrimidine-2(3H)-thione as novel, selective and potent adenosine A2A receptor antagonist. Neurosci. Lett. 2013, 558, 203-207. [CrossRef]

23. Kinoshita, H.; Hasegawa, T.; Katsumata, Y.; Kameyama, T.; Yamamoto, I.; Nabeshima, T. Effect of dizocilpine (MK-801) on the catalepsy induced by delta 9-tetrahydrocannabinol in mice. J. Neural. Transm. 1994, 95, 137-143. [CrossRef]

Sample Availability: Sample Availability: Sample of the compound PX-D-P6 is available from the authors.

(C) 2017 by the authors. Licensee MDPI, Basel, Switzerland. This article is an open access article distributed under the terms and conditions of the Creative Commons Attribution (CC BY) license (http://creativecommons.org/licenses/by/4.0/). 